\title{
Application of technology in educating nursing students during COVID-19: A systematic review
}

\author{
Ghazaleh Mohammadi ${ }^{1}$, Fateme Pezeshki ${ }^{1}$, Yeganeh Mohammadhosseinzadeh Vatanchi ${ }^{1}$, \\ Fateme Moghbeli2*(i)
}

${ }^{1}$ Bachelor Student of HIT, Department of Health Information Technology, Varastegan Institute for Medical Sciences, Mashhad, Iran ${ }^{2} \mathrm{PhD}$ in Medical Informatics, Assistant Professor, Department of Health Information Technology, Varastegan Institute for Medical Sciences, Mashhad, Iran

\begin{tabular}{|c|c|}
\hline Article Info & A B S T R A C T \\
\hline $\begin{array}{l}\text { Article type: } \\
\text { Review }\end{array}$ & $\begin{array}{l}\text { Introduction: In the crisis of Corona virus epidemic, the education of } \\
\text { undergraduate nursing students has faced many challenges. Face-to-face } \\
\text { training is closed and academics are forced to adapt to distance learning. As }\end{array}$ \\
\hline $\begin{array}{l}\text { Article History: } \\
\text { Received: 2021-01-02 }\end{array}$ & $\begin{array}{l}\text { a result, nursing students may encounter unfamiliar technologies. This } \\
\text { article provides examples of technologies used to provide nursing education. }\end{array}$ \\
\hline $\begin{array}{l}\text { Accepted: 2021-02-21 } \\
\text { Published: } 2021-02-28\end{array}$ & $\begin{array}{l}\text { Material and Methods: This research is an applied study that was } \\
\text { conducted in } 2021 \text { by systematic review method. Using the keywords of e- }\end{array}$ \\
\hline $\begin{array}{l}\text { * Corresponding author: } \\
\text { Fateme Moghbeli }\end{array}$ & $\begin{array}{l}\text { learning, nursing students, Corona virus and Covid- } 19 \text { were found in various } \\
\text { databases such as PubMed, Science Direct and Google scholar in the last two } \\
\text { years (2019-2020) due to the prevalence of coronary heart disease. }\end{array}$ \\
\hline $\begin{array}{l}\text { Assistant Professor, Department of } \\
\text { Health Information Technology, } \\
\text { Varastegan Institute for Medical } \\
\text { Sciences, Mashhad, Iran }\end{array}$ & $\begin{array}{l}\text { According to the inclusion and exclusion criteria of the study, which was the } \\
\text { time period and English language of the articles, related articles were } \\
\text { included in the study, their information was extracted and entered in the } \\
\text { checklist, and finally the collected data were analyzed using descriptive }\end{array}$ \\
\hline Email:fateme.moghbeli@gmail.com & $\begin{array}{l}\text { statistics. Incoming and outgoing articles are reported using the PRISMA } \\
\text { flowchart. }\end{array}$ \\
\hline \multirow[t]{2}{*}{$\begin{array}{l}\text { Keywords: } \\
\text { Educational Technologies } \\
\text { E-learning } \\
\text { Nursing students } \\
\text { Corona virus } \\
\text { Covid-19 }\end{array}$} & $\begin{array}{l}\text { Results: In this study, } 275 \text { English articles were found. After reviewing the } \\
\text { articles, } 12 \text { articles were included in the study. Studies conducted from } 2019 \\
\text { to } 2020 \text { in the field of e-learning for nursing students. In these articles, eight } \\
\text { educational methods for educating nursing students have been introduced, } \\
\text { and the use of cloud space for loading course materials and the use of } \\
\text { software that can be installed on smartphones were mentioned in } 83 \% \text { of } \\
\text { the articles. The use of Zoom, SoundCloud, Microsoft Teams and Blackboard } \\
\text { Collaborate software for loading webinars was suggested in } 91 \% \text { of the } \\
\text { articles. }\end{array}$ \\
\hline & $\begin{array}{l}\text { Conclusion: According to the findings of this article, it was found that most } \\
\text { studies have been conducted to introduce applied software to provide } \\
\text { practical courses, which due to the practical nature of many nursing courses, } \\
\text { the software have a high capability. }\end{array}$ \\
\hline
\end{tabular}

Cite this paper as:

Mohammadi G, Pezeshki F, Mohammadhosseinzadeh Vatanchi Y, Moghbeli F. Application of Technology in Educating Nursing Students During COVID-19: A Systematic Review. Front Health Inform. 2021; 10: 64. DOI: 10.30699/fhi.v10i1.273

\section{INTRODUCTION}

The nursing profession is in an unprecedented situation due to the COVID-19 epidemic [1]]. Nurses' training has also faced unprecedented conditions. Undergraduate nursing training programs generally offer a wide range of learning strategies. The Nursing and Midwifery Council and the European Union explicitly stated that nursing and assessment training should be provided in both practical and theoretical areas $[\underline{2}, \underline{3}]$.

In the critical condition of the COVID-19 Pandemic, the Nursing and Midwifery Council (NMC) has developed emergency standards for nursing and midwifery education that enable students in the last 6 months of their studies to practice in private clinics while maintaining social distance. And be trained in special circumstances $[\underline{4}, \underline{5}]$.

The closure of universities has disrupted teaching 
and learning as we know it, and overnight there has been a need for a change in the way nurse education is provided. Nursing students should use digital technologies as a way to learn the theoretical and practical part of their nursing curriculum. In the other hand, the challenges facing undergraduate nurse teaching during the current coronavirus pandemic include shifting to a completely virtual approach to theoretical teaching and learning [ㅇ-ㅁ].

knowing the best technologies and expectations of the nursing students when faced with virtual education by technologies, is necessary for helping the education and teaching authorities to assign enough resources and re-orient university education for nursing students [10]. To be able to manage this situation in an imminent future, it is necessary to learn from the strong and weak points of the technologies. Technologies can play an important role during this pandemic, it aims to help instructors and universities facilitate nursing student learning during periods of universities' closure. Besides, most of the systems are free which can help ensure continuous learning during the Coronavirus pandemic [11-16].

With the improvement of technology and digital capabilities, new opportunities emerge. Sessions can be delivered either via established methods including webinars on Zoom, Blackboard Collaborate or Microsoft Teams for nursing students. All of these tools are accessible via a smartphone, tablet or a computer. The aim of this study is to collect and report all examples of technologies used to provide nursing education during COVID-19 [1-22].

\section{MATERIAL AND METHODS}

PubMed, Science Direct and Google scholar were used to find studies and resources related to the use of technologies in the field of educating nursing students during COVID-19. English articles were searched from early 2019 to late 2010 using the educational Technologies, e-learning, nursing students, Corona Virus, and COVID-19 keywords.

These words were often used separately and in some cases as a combination of two words. Due to the fact that there was no specific time limit at the beginning of the search, most of the relevant articles extracted were related to the mentioned years. Incoming and outgoing articles are reported using the PRISMA flowchart [를 in Fig 1. About 275 titles were found and duplicate titles were removed. Emphasis was placed on empirical and review studies in the field of using technologies for educating nursing students during COVID-19. Finally, 12 articles were chosen.

The quality of the included studies will be assessed by the authors using appropriate instruments selected based on the type of each article. In case of disagreement, the consensus will be sought by the third reviewer.

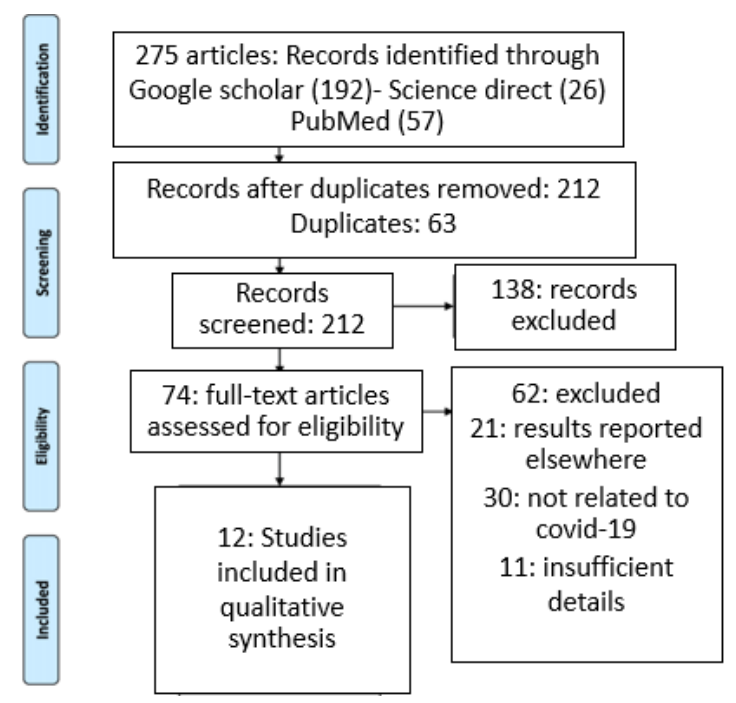

Fig 1: PRISMA flowchart

\section{RESULTS}

In this study, 275 English articles were found, which after a complete review of the texts, 12 articles were included in the study. The technologies that have been effective in the education of nursing students in the last two years are categorized in Table 1, which Zoom, Sound Cloud, Microsoft Teams and Blackboard Collaborate software were the most satisfactory ones from the users' point of view. The main usages of these programs are for webinars, virtual classrooms and Group work that are useful especially educating nursing students during the pandemic.

\section{Sound Cloud}

Sound Cloud is more than a streaming service, it's an open global community for anyone especially for nursing students to upload any sound for immediate discovery. It is an easy way to share the professors' podcast through this software [24].

\section{Microsoft Teams}

Microsoft Teams is a good software for teamwork, which brings together everything a nursing team needs: chat and threaded conversations, meetings \& video conferencing, calling, content collaboration with the power of Microsoft 365 applications.

Nursing students can also use Microsoft Teams to manage their personal life - chat, make plans, share shopping lists, tasks and even their location, coordinate events with family members or friends and make decisions quickly. It can easily move between students' work and personal account to stay organized throughout the day $[\underline{2}, \underline{5}]$. 
Table 1: Classification of widely used technologies in educating of nursing students during covid-19

\begin{tabular}{|c|c|c|c|c|}
\hline ?ं & 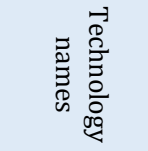 & 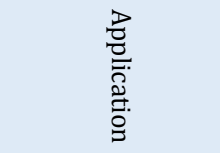 & 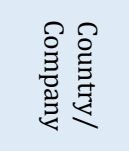 & 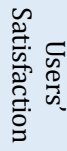 \\
\hline 1 & $\begin{array}{l}\text { Sound } \\
\text { Cloud [24] }\end{array}$ & Audio podcasts & Sweden & $90 \%$ \\
\hline 2 & $\begin{array}{l}\text { Microsoft } \\
\text { Teams [2] }\end{array}$ & $\begin{array}{l}\text { Webinars/virtual } \\
\text { classrooms }\end{array}$ & Microsoft & $84 \%$ \\
\hline 3 & Zoom [ㅁ] & $\begin{array}{l}\text { Webinars/virtual } \\
\text { classrooms } \\
\text { Activities } \\
\text { (independent or } \\
\text { group) }\end{array}$ & America & $72 \%$ \\
\hline 4 & $\begin{array}{l}\text { Blackboard } \\
\text { Collaborate } \\
{[\underline{25}]}\end{array}$ & $\begin{array}{l}\text { Webinars/virtual } \\
\text { classrooms } \\
\text { Group work }\end{array}$ & America & $50 \%$ \\
\hline
\end{tabular}

\section{Zoom}

That is a safe environment for meeting online. Nursing students can start or join a secure meeting with flawless video and audio, instant screen sharing, and cross-platform instant messaging - for free. It is one of the best communication experience on mobile $[\underline{2}, \underline{5}]$.

\section{Blackboard Collaborate}

It can help students stay informed, up-to-date and connected. With the Blackboard app, nursing students can quickly view updates to their courses and content, they can take assignments and tests and actually view grades for courses, assignments and tests [25].

This application functions as a collaborative tool between the app software and the institution's Blackboard Learn server. Blackboard cannot guarantee that the content created by instructors or other users will be compatible with this app. Access must be enabled by the institution. Features and functionality may at times be limited if the institution has not updated the appropriate software or experiences server outages $[\underline{25}, \underline{26}]$.

\section{DISCUSSION}

From this systematic review, Zoom, Sound Cloud, Microsoft Teams and Blackboard Collaborate technologies were the most important technologies that had been developed for educating nursing students especially during the COVID-19.

Most of the technologies identified from this systematic review were for webinars and they were useful for Practical training. These technologies were developed to facilitate the connection between nursing students and professors to make the education easier [27].

These four technologies that are categorized in Table
1 were user friendly and designed to ensure that most of the nursing students understood the application and used it effectively.

Konrad et al. showed that the most important point was ensuring useful learning activities were used to successfully meet the learning objectives in nursing fundamentals clinical courses that were emergently switched to an online format. This was achieved with interactive case studies, web-based learning activities, written work, online communication activities by zoom, and class discussions. These online activities enabled transparent assessment of core learning objectives and students clinical reasoning abilities, despite the missing traditional patient care component [료].

Lee et al. showed that zoom app is becoming increasingly popular amongst nursing students who are learning practical courses [29]. Malso showed that zoom app as the one of the best one for educating especially for nurses students [30].

Correia et al. showed Microsoft Teams as the best app for videoconferencing for nursing students [31]. Blackboard Collaborate is also introduced as the best app for practical and theoretical courses for nursing students and it was showed by Leigh et al. []].

Finally Udy-Janczuk showed Sound Cloud as one of the best apps for recording and making podcast for nursing students [32].

The analysis shows that technologies can be effective in educating the nursing students during the COVID19. This systematic review managed to identify certain technologies that can facilitate the nursing education in both theoretical and practical.

\section{CONCLUSION}

This systematic review has identified a variety of technologies that may be potentially useful to educate the nursing students during the spread of COVID-19. The majority of the technologies were for the purposes of meeting and webinars. However, these technologies, especially those for meeting, can be effective if they are advocated by the professors and universities. Governments can also benefit by encouraging their nursing students and professors to use these technologies during the pandemic. In addition, the sharing of good practices across different countries with new technologies can enable governments to learn from each other.

Finally, it is not clear when the universities will open. Therefore, the use of digital technologies in interaction with students and those health care practitioners who support the education and evaluation of students from within the clinical learning environment should be expanded.It is also very important that students feel supported by professors while engaging in clinical practice at these 
unprecedented times.

\section{AUTHOR'S CONTRIBUTION}

The authors agree on this final form of the manuscript, and attested that all authors contributed in the final draft of the manuscript.

\section{CONFLICTS OF INTEREST}

The authors declare no conflicts of interest regarding the publication of this study.

\section{FINANCIAL DISCLOSURE}

No financial interests related to the material of this manuscript have been declared.

\section{REFERENCES}

1. Heslin SM, Nappi M, Kelly G, Crawford J, Morley EJ, Lingam V, et al. Rapid creation of an emergency department telehealth program during the COVID-19 pandemic. J Telemed Telecare. 2020; 1357633X20952632. PMID: 32873137 DOI: 10.1177/1357633X20952632 [ubMed]

2. Henry A, Shellenbarger T. To zoom or not to zoom? Choosing a videoconferencing platform. Nurse Author \& Editor. 2020; 30(4): 3.

3. O'Sullivan K, McGrane A, Clark S, Marshall K. Exploring the impact of home-schooling on the psychological wellbeing of Irish families during the novel coronavirus (COVID-19) pandemic: A qualitative study protocol. International Journal of Qualitative Methods. 2020; 19: 1609406920980954.

4. Leigh J, Vasilica C, Dron R, Gawthorpe D, Burns E, Kennedy $\mathrm{S}$, et al. Redefining undergraduate nurse teaching during the coronavirus pandemic: use of digital technologies. Br J Nurs. 2020; 29(10): 566-9. PMID: $32463742 \quad$ DOI: 10.12968/bjon.2020.29.10.566 [ubMed]

5. Llerena-Izquierdo J, Barcia-Ayala O, Ayala-Carabajo R. Faculty training through crowdlearning for emerging online education. IEEE ANDESCON. IEEE; 2020.

6. Baccin CRA, Dal Sasso GTM, Paixão CA, de Sousa PAF. Mobile application as a learning aid for nurses and nursing students to identify and care for stroke patients: Pretest and posttest results. Comput Inform Nurs. 2020; 38(7): 358-66. PMID: 32427611 DOI: 10.1097/CIN.0000000000000623 [PubMed]

7. Brinker TJ, Alfitian J, Seeger W, Groneberg DA, von Kalle C, Enk AH, et al. A face-aging smoking prevention/cessation intervention for nursery school students in Germany: An appearance-focused interventional study. Int J Environ Res Public Health. 2018; 15(8): 1656. PMID: 30081549 DOI: 10.3390/ijerph15081656 [PubMed]

8. Chakraborty TR, Cooperstein DF. Exploring anatomy and physiology using iPad applications. Anat Sci Educ. 2018; 11(4): 336-45. PMID: 29112797 DOI: 10.1002/ase.1747 [PubMed]

9. Cheng SF. Application of creative teaching. Hu Li Za Zhi. 2018; 65(6): 4. PMID: 30488406 DOI: 10.6224/JN.201812_65(6).01 [PubMed]

10. Sayadi M, Moghbeli F, Mehrjoo H, Mahaki M. A linear study of the spread of COVID19 in China and Iran. Front Health Inform. 2020; 9(1): 32.
11. Choi EP, Wong JY, Lo HH, Wong W, Chio JH, Fong DY. The impacts of using smartphone dating applications on sexual risk behaviours in college students in Hong Kong. PloS One. 2016; 11(11): e0165394. PMID: 27828997 DOI: 10.1371/journal.pone.0165394 [PubMed]

12. Choi EP, Wong JY, Lo HH, Wong W, Chio JH, Fong DY. Association between using smartphone dating applications and alcohol and recreational drug use in conjunction with sexual activities in college students. Subst Use Misuse. 2017; 52(4): 422-8. PMID: 27849418 DOI: $10.1080 / 10826084.2016 .1233566$ [PubMed]

13. Colton S, Hunt L. Developing a smartphone app to support the nursing community. Nurs Manag (Harrow). 2016; 22(9): 24-8. PMID: 26938912 DOI: 10.7748/nm.22.9.24.s28 [PubMed]

14. de Jong A, Donelle L, Kerr M. Nurses' use of personal smartphone technology in the workplace: Scoping review. JMIR Mhealth Uhealth. 2020; 8(11): e18774. PMID: 33242012 DOI: 10.2196/18774 [PubMed]

15. Dodson $\mathrm{CH}$, Baker E. Focus group testing of a mobile app for pharmacogenetic-guided dosing. J Am Assoc Nurse Prac. 2020. Online ahead of print. PMID: 32039960 DOI: $10.1097 / J X X .0000000000000392$ [PubMed]

16. Elliott K, Marks-Maran D, Bach R. Teaching student nurses how to use electronic patient records through simulation: A case study. Nurse Educ Prac. 2018; 30: 7-12. PMID: 29459316 DOI: 10.1016/j.nepr.2018.02.003 [PubMed]

17. George TP, DeCristofaro C. Use of smartphones with undergraduate nursing students. J Nurs Educ. 2016; 55(7): 411-5. PMID: 27351612 DOI: 10.3928/01484834-20160615-11 [PubMed]

18. Glass N, Clough A, Case J, Hanson G, Barnes-Hoyt J, Waterbury A, et al. A safety app to respond to dating violence for college women and their friends: The MyPlan study randomized controlled trial protocol. BMC Public Health. 2015; 15: 871. PMID: 26350482 DOI: 10.1186/s12889-015-2191-6 [ubMed]

19. Hardie P, Darley A, Carroll L, Redmond C, Campbell A, Jarvis S. Nursing \& Midwifery students' experience of immersive virtual reality storytelling: An evaluative study. BMC Nurs. 2020; 19: 78. PMID: 32821245 DOI: 10.1186/s12912-020-00471-5 [ubMed]

20. Hopkins C. School nurse matters. Nurs Stand. 2015; 29(41): $31 . \quad$ PMID: 26058641 DOI: 10.7748/ns.29.41.31.s33 [PubMed] 
21. Hoplock LB, Lobchuk MM, Lemoine J. Perceptions of an evidence-based empathy mobile app in postsecondary education. Educ Inf Technol (Dordr). 2020; 2020: 1-20. PMID: 32863732 DOI: 10.1007/s10639020-10311-3 [ubMed]

22. Hsu LL, Hsiang HC, Tseng YH, Huang SY, Hsieh SI. Nursing students' experiences of using a smart phone application for a physical assessment course: A qualitative study. Jpn J Nurs Sci. 2019; 16(2): 115-24. PMID: 29947101 DOI: 10.1111/jjns.12215 [PubMed]

23. Hutton B, Salanti G, Caldwell DM, Chaimani A, Schmid $\mathrm{CH}$, Cameron $\mathrm{C}$, et al. The PRISMA extension statement for reporting of systematic reviews incorporating network meta-analyses of health care interventions: checklist and explanations. Ann Intern Med. 2015; 162(11): 777-84. PMID: 26030634 DOI: 10.7326/M14-2385 [PubMed]

24. Hernandez-de-Menendez M, Díaz CAE, MoralesMenendez R. Educational experiences with Generation Z. International Journal on Interactive Design and Manufacturing. 2020; 14(3): 847-59.

25. González-Durán M, Hernández-Sánchez T, CuevasRodríguez J, López-Lambraño Á, editors. The Use of blackboard ultra for synchronous and asynchronous online communication: Case study at the autonomous university of Baja California. Annual International Conference of Education, Research and Innovation. Digital Library; 2020.

26. O'Connor S, Daly CS, MacArthur J, Borglin G, Booth RG.
Podcasting in nursing and midwifery education: An integrative review. Nurs Educ Prac. 2020; 47: 102827. PMID: 32763834 DOI: 10.1016/j.nepr.2020.102827 [PubMed]

27. Khan IA. Electronic learning management system: Relevance, challenges and preparedness. Journal of Emerging Technologies and Innovative Research. 2020; 7(5): 471-80.

28. Konrad S, Fitzgerald A, Deckers C. Nursing fundamentals-supporting clinical competency online during the COVID-19 pandemic. Teach Learn Nurs. 2021; 16(1): 53-6. PMID: 32837448 DOI: 10.1016/j.teln.2020.07.005 [PubMed]

29. Lee RL, West $\mathrm{S}$, Tang AC, Cheng $\mathrm{H}$, Chong CY, Chien $\mathrm{W}$, et al. A qualitative exploration of the experiences of school nurses during COVID-19 pandemic as the frontline primary health care professionals. Nurs Outlook. 2020; 6554(20): 30710-7. PMID: 33541726 DOI: 10.1016/j.outlook.2020.12.003 [PubMed]

30. Jafar M, Shoukat A. Factors affecting performance of healthcare workers during COVID-19 in Pakistan. Space and Culture, India. 2020; 8(2): 62-73.

31. Correia A-P, Liu C, Xu F. Evaluating videoconferencing systems for the quality of the educational experience. Distance Education. 2020; 41(4): 429-52.

32. Udy-Janczuk SB. Nurse leader seeks to understand, then to be understood [PhD Thesis]. Wilmington University (Delaware); 2020. 